\author{
Katarzyna Klimas* \\ ORCID: 0000-0003-4490-8531 \\ Uniwersytet Wrocławski
}

DOI: $10.19195 / 1733-5779.26 .6$

\title{
Prawo pacjenta do dostępu do elektronicznej dokumentacji medycznej
}

JEL Classification: I1, K1, K3

Slowa kluczowe: elektroniczna dokumentacja medyczna, prawo do informacji, informacja w ochronie zdrowia, System Informacji Medycznej, prawa pacjenta, prawo medyczne

Keywords: electronic medical records, right to information, information in healthcare, Polish Medical Information System, patient's rights, medical law

\begin{abstract}
Abstrakt: Przedmiotowy artykuł poświęcony jest zagadnieniu elektronicznej dokumentacji medycznej jako narzędzia do realizacji prawa pacjenta do informacji. Asumptem do analizy w tym zakresie jest obowiązek prowadzenia dokumentacji medycznej wyłącznie w postaci elektronicznej obowiązujący od 1 stycznia 2018 roku, a także umożliwienie udostępniania dokumentacji w Systemie Informacji Medycznej planowanego od dnia 1 sierpnia 2017 roku. Zasadniczej zmianie ulegnie zatem forma, w jakiej pacjent będzie uzyskiwał dostęp do dokumentacji i realizował swoje informacyjne uprawnienia.

W niniejszej pracy autorka dokona oceny prognozowanych zmian prawnych, poczynając od wyjaśnienia pojęcia „elektroniczna dokumentacja medyczna” oraz określenia tła historycznego. W dalszej części stanowiącej kluczowy fragment artykułu przedstawione zostaną korzyści wynikające $\mathrm{z}$ prowadzenia i przetwarzania dokumentacji medycznej w postaci elektronicznej oraz główne przeszkody w korzystaniu z dostępu do elektronicznej dokumentacji medycznej w systemie teleinformatycznym.
\end{abstract}

\section{The patient's right to access to electronic medical records}

Abstract: The article is devoted to the issue of electronic medical records as a progressive instrument of implementation the patient's right to information. Reason for such analysis is an obligation of archiving medical records only in electronic form (in force since 1 January 2018) as well as possibility to share documentation in the Polish Medical Information System (planned from

* Opiekun naukowy (Scientific Tutor) — Jacek Gołaczyński 
1 August 2017). Therefore there is a fundamental change in the form in which the patient will obtain access to the records and perform his information rights.

In following considerations, the author will peform evaluation of expected law modifications, starting with explanation of the term ,electronic medical records" and marking the historical background of development in this range. In the further part, will be presented the advantages of processing electronic.

\section{Wstęp}

We współczesnych stosunkach między pacjentem a lekarzem, opartych na zasadzie poszanowania autonomii decyzyjnej tego pierwszego, podstawowym obowiązkiem medyka pozostaje udzielenie pacjentowi kompletnej informacji na temat jego stanu zdrowia. Prawo do informacji, wynikające z art. 9 u.p.p. ${ }^{1}$, jest bowiem fundamentem realizacji innych uprawnień pacjenta, jak prawo do wyrażenia świadomej zgody na leczenie czy prawo do udzielenia świadczenia zdrowotnego. Założenie o konieczności zapewnienia pacjentowi pełnej i rzetelnej informacji na temat jego stanu zdrowia, a także udzieleniu mu tej informacji w sposób dla niego przystępny, leży u podstaw uznania, że w relacji między lekarzem a pacjentem to właśnie pacjent ma decydujący głos, a rolą lekarza jest służenie pomocą zgodnie z wolą pacjenta. Aby jednak mówić o woli czy świadomości w procesie decyzyjnym, niezbędne jest zapewnienie pacjentowi wiedzy pozwalającej mu na samodzielną ocenę jego stanu zdrowia oraz potrzeb w zakresie jego ochrony ${ }^{2}$. Nie ma bowiem uzasadnienia dla działań paternalistycznych ze strony lekarza, nawet gdy faktycznie jest w stanie lepiej, bo z wykorzystaniem specjalistycznej wiedzy, ocenić, co dla pacjenta byłoby odpowiednie.

Nie wdając się w rozległą problematykę określenia granic lekarskiego obowiązku informowania oraz odpowiedzialności związanych z naruszeniami w tym zakresie ${ }^{3}$, należy wskazać, że emanacją ogólnego prawa pacjenta do informacji o stanie zdrowia jest prawo do dokumentacji medycznej. Zgodnie z art. 23 ust. 1 u.p.p. pacjent ma prawo do dostępu do dokumentacji medycznej dotyczącej jego stanu zdrowia oraz udzielonych mu świadczeń zdrowotnych ${ }^{4}$. Z samej konstrukcji prawnej prawa do dokumentacji medycznej nie wynika w żaden sposób związanie tego uprawnie-

${ }^{1}$ Ustawa z dnia 6 listopada 2008 roku o prawach pacjenta i Rzeczniku Praw Pacjenta (Dz.U. 2016 r., poz. 286, ze zm.), dalej ,u.p.p.”.

2 K. Bączyk-Rozwadowska, Prawo pacjenta do informacji wedtug przepisów polskiego prawa medycznego, „Studia Iuridica Toruniensia” 9, 2011, nr 2, s. 60.

3 Por. K. Michałkowska, Informowanie pacjenta w polskim prawie medycznym, ,Prawo i Medycyna” 2003, nr 13; M. Sośniak, Obowiazek powiadomienia o skutkach zabiegu lekarskiego, „Państwo i Prawo" 1958, nr 7; T. Dukiet-Nagórska, Świadoma zgoda pacjenta w ustawodawstwie polskim, „Prawo i Medycyna” 2000, nr 6-7; J. Radzicki, Ryzyko zabiegów leczniczych w prawie karnym, Warszawa 1967; B. Janiszewska, Zgoda na udzielenie świadczenia zdrowotnego. Ujęcie wewnatrzsystemowe, Warszawa 2013, s. 415 n.

${ }^{4}$ U. Drozdowska, Tworzenie dokumentacji medycznej, [w:] Dokumentacja medyczna, red. U. Drozdowska, Warszawa 2012, s. 23. 
nia wyłącznie z prawem do wyrażenia zgody. Ustawodawca nie ograniczył funkcji prawa do dostępu do dokumentacji medycznej jedynie do ułatwienia zdobycia wiadomości niezbędnych pacjentowi do podjęcia świadomej decyzji o leczeniu.

Prawo do informacji występuje zarówno w powiązaniu z prawem do wyrażenia zgody, jak i samoistnie, realizując inne cele ${ }^{5}$. Samo uprawnienie do uzyskania dostępu do dokumentacji medycznej jest zapewnione pacjentowi ${ }^{6}$ zarówno w trakcie trwania leczenia, jak i po jego zakończeniu przez czas określony w przepisach regulujących zasady archiwizacji dokumentacji medycznej ${ }^{7}$. Oznacza to zatem, że prawo pacjenta do dokumentacji medycznej umożliwia pacjentowi dysponowanie dokumentacja medyczną ${ }^{8}$ do innych celów. W tym miejscu wskazać można choćby kontynuowanie leczenia w innej placówce zdrowotnej czy wykorzystanie dokumentacji medycznej jako dowodu w postępowaniu sądowym lub w postępowaniu przed wojewódzką komisją do spraw orzekania o zdarzeniach medycznych ${ }^{9}$.

Realizacja uprawnienia pacjenta do dokumentacji medycznej pociąga za sobą wiele problemów natury organizacyjnej i technicznej. Prowadzenie, przechowywanie oraz udostępnianie dokumentacji medycznej prowadzonej w tradycyjnej postaci papierowej pozostawało nieekonomiczne oraz niepraktyczne zarówno dla pacjentów, jak i dla lekarzy. Ułatwieniem ma być dokumentacja medyczna prowadzona w postaci elektronicznej. Z uwagi na powyższe zasadne jest dokonanie oceny projektowanych zmian oraz wykorzystania elektronicznej dokumentacji medycznej jako narzędzia do realizacji prawa pacjenta do informacji. W niniejszym artykule wykorzystano metodę dogmatycznoformalną, charakterystyczną dla badań w prawoznawstwie.

\section{Podstawy wprowadzenia obowiązku prowadzenia dokumentacji medycznej w postaci elektronicznej}

Za początek wdrażania informatycznych rozwiązań w zakresie informacji w ochronie zdrowia należy uznać drugą połowę XX wieku, kiedy to na szeroką skalę zaczęto prowadzić elektroniczne rejestry medyczne (tak zwane electroni-

5 U. Drozdowska, W. Wojtal, Zgoda i informowanie pacjenta, Warszawa 2010, s. 45.

6 Zgodnie z art. 26 u.p.p. prawo do dokumentacji medycznej przysługuje nie tylko pacjentowi, lecz także jego przedstawicielowi ustawowemu oraz innym podmiotom wskazanym w ustawach. Niemniej z uwagi na uregulowanie tego uprawnienia jako pierwotnie przysługującego pacjentowi, przedmiotowy artykuł będzie dotyczył wyłącznie prawa pacjenta do dokumentacji medycznej (prowadzonej w postaci elektronicznej).

7 Jest to co do zasady okres 20 lat, z wyjątkiem dokumentacji określonej w art. 29 ust. 1 u.p.p.

8 Sama dokumentacja medyczna stanowi własność podmiotu prowadzącego dokumentację (tak U. Drozdowska, op. cit., s. 25), niemniej pacjent ma prawo do uzyskania kopii, odpisów i wydruków stosownie do art. 27 u.p.p. i w takim kontekście dysponuje dokumentacją medyczną, wykorzystując ją do własnych celów.

9 H. Frąckowiak, Postępowanie przed wojewódzką komisją do spraw orzekania o zdarzeniach medycznych, Warszawa 2016, s. 279-283, 304-306. 
cal health records - EHR) ${ }^{10}$. Dostrzeżenie potencjału wykorzystania systemów teleinformatycznych w organizacji ochrony zdrowia, w procesie diagnostyczno-terapeutycznym oraz realizacji praw pacjenta, skutkujący dostrzegalną poprawą jakości świadczonych usług, spowodował znaczną intensyfikację działań zmierzających do wdrażania kompleksowych elektronicznych systemów opieki zdrowotnej ${ }^{11}$. Asumptem do podejmowania kroków ku unowocześnieniu funkcjonowania placówek leczniczych było także rosnące wykorzystanie elektronicznej dokumentacji medycznej w Stanach Zjednoczonych ${ }^{12}$ oraz innych państwach poza Europą ${ }^{13}$.

Nie bez znaczenia dla rozwoju tej dziedziny w Polsce pozostały kierunki określone przez Unię Europejską, czego przykładem może być Europejska Agenda Cyfrowa ${ }^{14}$, tworzące jeden z siedmiu filarów strategii Europa 2020. Jednym z obszarów działań jest zapewnienie stabilnej opieki zdrowotnej oraz niezależnego życia poprzez wdrożenie i wykorzystanie innowacyjnych technologii w medycynie. Wyzwanie to wiąże się bezpośrednio ze zjawiskiem starzenia się społeczeństw europejskich i rosnącymi kosztami związanymi z zapewnieniem świadczeń zdrowotnych na odpowiednim poziomie ${ }^{15}$. Głównym działaniem w tym obszarze jest zapewnienie Europejczykom bezpiecznego dostępu do ich danych medycznych za pomocą Internetu (główne działanie nr 13, pkt 2.7.1 komunikatu).

$\mathrm{W}$ odpowiedzi na te przemiany oraz potrzebę wykreowania nowego modelu „cyfrowego" pacjenta, ale także celem prawnego uregulowania praktyki i zapewnienia odpowiedniego poziomu dostępu do informacji w ochronie zdrowia, która determinuje jakość świadczeń zdrowotnych ${ }^{16}$, polski ustawodawca również zdecydował się wprowadzić obowiązek prowadzenia dokumentacji medycznej w postaci elektronicznej. Zgodnie z art. 11 u.s.i.o.z. ${ }^{17}$ planowo $^{18}$ od dnia 1 stycznia 2018 roku

10 A. Klich, K. Smyk, Udostępnianie elektronicznej dokumentacji medycznej — zagadnienia praktyczne, [w:] E-państwo. E-obywatel. E-ustugi, red. K. Flaga-Gieruszyńska, J. Gołaczyński, D. Szostek, Warszawa 2017.

11 Ibidem.

$12 \mathrm{H}$. Fraser et al., Implementing electronic medical record systems in developing countries, „Informatics in Primary Care” 2005, nr 13, s. 84; S.V. Katikireddi, HINARI: Bridging the global information divide, „British Medical Journal” 2004, nr 328, s. 1190-1193.

13 G. Pynt, Australia: medical records — access by patient, „International Insurance Law Review" 1995, nr 3, s. 179-181.

14 Komunikat Komisji do Parlamentu Europejskiego, Rady, Europejskiego Komitetu Ekonomiczno-Społecznego i Komitetu Regionów „Europejska Agenda Cyfrowa” (COM/2010/0245), Eur-Lex nr 52010DC0245(01), dalej „komunikat”.

${ }^{15} \mathrm{~K}$. Świtała, Nowy system informacji ochrony zdrowia w kontekście Europejskiej Agendy Cyfrowej, „Czas Informacji” 2011, nr 4, s. 6.

16 I. Bernatek-Zaguła, Prawo pacjenta do informacji zawartej $w$ dokumentacji medycznej, „Przegląd Prawa i Administracji” 69, 2005, s. 235 n.

17 Ustawa z dnia 28 kwietnia 2011 roku o systemie informacji w ochronie zdrowia (Dz.U. z 2016 r., poz. 1535 ze zm.), dalej ,u.s.i.o.z.”.

18 Należy jednak zauważyć, że termin wprowadzenia obligatoryjnej postaci elektronicznej dokumentacji medycznej był już przesuwany przez ustawodawcę dwukrotnie (początkowo był 
jedyną dopuszczalną formą dokumentacji medycznej w publicznej służbie zdrowia będzie właśnie forma elektroniczna. Obecnie dokumentacja medyczna może być prowadzona zarówno w formie tradycyjnej (papierowej), jak i elektronicz$n^{119}$. W wielu podmiotach leczniczych (zarówno działających w ramach publicznej opieki zdrowotnej, jak i świadczących usługi w sektorze prywatnym) z powodzeniem prowadzi się dokumentację medyczną w formie elektronicznej. Wyrazem takiej praktyki jest choćby nowelizacja ${ }^{20}$ art. 27 u.p.p., który reguluje sposoby udostępniania dokumentacji medycznej, odnosząc się także do elektronicznej dokumentacji medycznej. Co jednak niezwykle istotne, od 1 stycznia 2018 roku dokumentacja medyczna prowadzona w postaci elektronicznej będzie udostępniania za pomocą Systemu Informacji Medycznej, będącego zintegrowanym systemem teleinformatycznym, w którym gromadzone oraz przechowywane są dane dotyczące udzielonych, udzielanych i planowanych świadczeń opieki zdrowotnej (art. 10 u.s.i.o.z.). Zasadniczej zmianie ulegnie zatem sposób, w jaki pacjent będzie mógł zrealizować przysługujące mu prawo dostępu do dokumentacji medycznej oraz prawo do informacji.

\section{Pojęcie elektronicznej dokumentacji medycznej}

Dążenie do ułatwienia pacjentom dostępu do informacji w ochronie zdrowia należy ocenić jako pozytywny kierunek zmian. Przetwarzanie elektronicznej dokumentacji medycznej w systemie teleinformatycznym jest znacznym wyzwaniem organizacyjnym i technicznym, stąd też warto pochylić się nad samym pojęciem elektronicznej dokumentacji medycznej, określenia najważniejszych zalet takiej formy prowadzenia dokumentacji, a także niebezpieczeństw związanych z wykorzystywaniem Internetu.

Ustawa o prawach pacjenta i Rzeczniku Praw Pacjenta nie definiuje pojęcia dokumentacji medycznej (czy elektronicznej dokumentacji medycznej), określającego wyłącznie prawo pacjenta (i innych podmiotów) do dostępu do niej oraz sposobów jej prowadzenia i udostępniania. Również ustawa z dnia 15 kwietnia 2011 roku o działalności leczniczej ${ }^{21}$ nie wyjaśnia tego terminu, odsyłając $\mathrm{w}$ art. 2 ust. do znaczenia nadanego pojęciu dokumentacji medycznej nadanego przepisa-

to 1 sierpnia 2014 roku, następnie 1 sierpnia 2017 roku), stąd też obecnego wiążącego terminu nie należy traktować jako ostateczny.

19 Rozporządzenie Ministra Zdrowia z dnia 9 listopada 2015 roku w sprawie rodzajów, zakresu i wzorów dokumentacji medycznej oraz sposobu jej przetwarzania (Dz.U. z 2015 r., poz. 2069, ze zm.), § 1, dalej ,rozporządzenie ws. dokumentacji”.

${ }^{20}$ Ustawa z dnia 9 października 2015 roku o zmianie ustawy o systemie informacji w ochronie zdrowia oraz niektóry innych ustaw (Dz.U. z 2015 r., poz. 1991, ze zm.), która weszła w życie 12 grudnia 2015 roku.

21 Ustawa z dnia 15 kwietnia 2011 roku o działalności leczniczej (Dz.U. z 2016 r., poz. 1638, ze zm.), dalej ,u.d.l.”. 
mi u.p.p. Brakuje zatem w polskim prawie ogólnej ustawowej definicji dokumentacji medycznej, która w sposób precyzyjny określiłaby zakres tego pojęcia ${ }^{22}$. Nie sposób w tym miejscu nie odwołać się do definicji zawartej w art. 18 d ust. 1 pkt 5 nieobowiązującej już ustawy z dnia 30 sierpnia 1991 roku o zakładach opieki zdrowotnej ${ }^{23}$. Wskazany przepis, zgodnie $\mathrm{z}$ którym dokumentacja medyczna to dane i informacje medyczne odnoszące się do stanu zdrowia pacjenta lub udzielonych mu w zakładzie opieki zdrowotnej świadczeń zdrowotnych, gromadzone i udostępniane na zasadach określonych w u.p.p., może być pewnie punktem odniesienia do ustalenia zakresu pojęcia dokumentacji medycznej. Pomijając okoliczność, że powyższa definicja odnosi się wyłącznie do świadczeń zdrowotnych udzielanych w zakładach opieki zdrowotnej, na jej podstawie można sformułować ogólne stwierdzenie, że dokumentacja medyczna to zbiór danych opisujących stan zdrowia pacjenta oraz zakres udzielanych mu świadczeń ${ }^{24}$. Tak ustalone znaczenie dokumentacji medycznej odnosi się jednak wyłącznie do tak zwanej dokumentacji indywidualnej, w rozumieniu $\S 2$ ust. 1 pkt 1 rozporządzenia ws. dokumentacji, a zatem dokumentacji dotyczącej danego, konkretnego pacjenta. Termin „dokumentacja medyczna" jest jednak szerszy, albowiem obejmuje także dokumentację zbiorczą, zawierającą dane dotyczące ogółu pacjentów lub grup pacjentów korzystających ze świadczeń zdrowotnych (§ 2 ust. 1 pkt 2 rozporządzenia ws. dokumentacji). Zagadnienie zbiorczej dokumentacji medycznej jest o tyle istotne, że pacjent ma prawo dostępu także do danych zawartych w tej dokumentacji, o ile dotyczą jego osoby ${ }^{25}$.

Zawartość dokumentów tworzących dokumentację medyczną jest różna, w zależności od podmiotu je sporządzającego (na przykład lekarz), niemniej z art. 25 u.p.p. wynikają minimalne wymagania co do dokumentacji tworzonej w procesie diagnostyczno-terapeutycznym. Według R. Kubiaka brak któregokolwiek z wymienionych we wskazanymi przepisie elementów powoduje, że dany dokument nie może być uznany za dokumentację medyczną ${ }^{26}$.

Powyższe skłania ku zdefiniowaniu dokumentacji medycznej jako zbioru danych zawierających dane pacjentów, dotyczących ich stanu zdrowia oraz udzielanych świadczeń zdrowotnych, spełniających wymagania przewidziane w u.p.p., podlegających tworzeniu, gromadzeniu, przetwarzaniu i udostępnianiu na zasadach w niej określonych.

22 A. Górski, Dokumentacja medyczna, [w:] Leksykon prawa medycznego, red. A. Górski, Warszawa 2012, s. 19.

23 Dz.U. z 2007 r. Nr 14, poz. 89, ze zm. (akt utracił moc obowiązującą 4 kwietnia 2011 roku).

24 R. Kubiak, Prawo medyczne, Warszawa 2010, s. 246.

25 R. Kubiak, Tajemnica medyczna, Warszawa 2015, s. 207, por. wyrok Naczelnego Sądu Administracyjnego z dnia 11 stycznia 2007 roku, I OSK 251/06, LEX.

${ }^{26}$ R. Kubiak, Prawo medyczne..., s. 247. Autor czyni jednak uwagę, że jeżeli taki nośnik informacji zawiera dane osobowe pacjenta, podlega ochronie na zasadach przewidzianych w ustawie z dnia 29 sierpnia 1997 roku o ochronie danych osobowych (Dz.U. z 2016 r., poz. 922, ze zm.), ibidem. 
Z kolei elektroniczna dokumentacja medyczna została zdefiniowana w art. 2 ust. 1 pkt 6 u.s.i.o.z. jako dokument elektroniczny umożliwiający usługobiorcy uzyskanie świadczenia opieki zdrowotnej określonego rodzaju, w wypadku usługodawcy będącego świadczeniodawcą ${ }^{27}$, apteką ogólnodostępną lub punktem aptecznym oraz dokumentację medyczną indywidualną, z wyłączeniem skierowań, wytworzoną w postaci elektronicznej. Pojęcie elektronicznej dokumentacji medycznej zostało zatem ograniczone do dokumentacji indywidualnej pacjenta, co nie oznacza, że zbiorowe dane medyczne nie są gromadzone i przetwarzane w systemie teleinformatycznym i nie mają postaci elektronicznej ${ }^{28}$. Nie wdając się w rozległą problematykę określenia technicznego znaczenia elektronicznej postaci dokumentu należącej do zagadnienia informatyki ${ }^{29}$, należy wskazać, że dokument elektroniczny został zdefiniowany przez prawodawcę europejskiego $\mathrm{w}$ art. 3 pkt 35 rozporządzenie eIDAS ${ }^{30}$, zgodnie z którym dokument elektroniczny to każda treść przechowywana w postaci elektronicznej, w szczególności tekst lub nagranie dźwiękowe, wizualne lub audiowizualne. Dokument elektroniczny ma przy tym postać cyfrowego zapisu danych, który tworzony jest za pomocą komputera $^{31}$ i który może być utrwalany na elektronicznych nośnikach informacji. Nie jest natomiast elektronicznym dokumentem wydruk tego dokumentu czy jego prezentacja na monitorze komputera, gdyż pozbawia to związku z informacjami zawartymi w metadanych tego dokumentu ${ }^{32}$. Tak rozumiany dokument elektroniczny, stanowiący pewien zapis cyfrowy informacji, którego przechowywanie oraz odczytywanie jest możliwe za pomocą urządzeń elektronicznych, odnosi się także do elektronicznej dokumentacji medycznej.

\section{Korzyści oraz zagrożenia związane ze stosowaniem elektronicznej dokumentacji medycznej w opiece zdrowotnej}

Przyczyny leżące u podstaw wprowadzenia do polskiego systemu prawnego formy elektronicznej jako jedynej dopuszczalnej formy prowadzenia dokumen-

27 W rozumieniu art. 5 pkt 41 ustawy z dnia 27 sierpnia 2004 roku o świadczeniach opieki zdrowotnej finansowanych ze środków publicznych (Dz.U. z 2015 r., poz. 581, ze zm.).

28 Wskazać tu można choćby funkcjonujące od lat rejestry medyczne (rozdział 4 u.s.i.o.z.).

29 J. Jankowski, Elektroniczny obrót prawny, Warszawa 2008, s. 164. Autor odwołuje się do normy technicznej PN-ISO 690-2.

30 Rozporządzenie Parlamentu Europejskiego i Rady UE nr 910/2014 z dnia 23 lipca 2014 roku w sprawie identyfikacji elektronicznej i usług zaufania w odniesieniu do transakcji elektronicznych na rynku wewnętrznym oraz uchylające dyrektywę 1999/93/WE (Dz.Urz. UE L Nr 326, s. 47).

31 K. Wojsyk, Informatyka w administracji publicznej nie przynosi oczekiwanych efektów ekonomicznych - i co ma do tego prawo?, [w:] Prawne problemy wykorzystania nowych technologii, red. K. Grajewski, J. Warylewski, Gdańsk 2008, s. 139.

32 D. Szostek, Komentarz do art. $77^{3}$ Kodeksu cywilnego, [w:] Informatyzacja postępowania cywilnego. Komentarz, red. J. Gołaczyński, D. Szostek, Warszawa 2016, s. 89. 
tacji medycznej są liczne. W dużej mierze odpowiadają tendencjom i kierunkom nadanym przez prawodawcę europejskiego, a także są odpowiedzią na rosnące potrzeby społeczeństwa i oczekiwania przedstawicieli zawodów medycznych. Warto, przed przystąpieniem do omówienia podstawowych problemów oraz zagrożeń związanych z prowadzeniem dokumentacji w postaci elektronicznej, wskazać zalety takiego rozwiązania w stosunku do tworzenia dokumentacji w sposób tradycyjny z punktu widzenia pacjenta oraz personelu medycznego.

Główne trudności związane z prowadzeniem dokumentacji medycznej w formie papierowej związane są z lokalizacyjnymi oraz ekonomicznymi barierami jej przechowywania i udostępniania. Dokumentacja medyczna jest, co do zasady, archiwizowana przez 20 lat, z wyjątkiem pewnych ustawowo wskazanych sytuacji ${ }^{33}$, co oznacza, że podmiot odpowiedzialny za przechowywanie dokumentacji musi zapewnić w tym celu odpowiednie warunki organizacyjne i przestrzenne, a także zabezpieczenia przed uszkodzeniem czy nieautoryzowanym dostępem, przy równoczesnym zagwarantowaniu możliwości wydobycia i wykorzystania dokumentacji w razie konieczności (§ 74 rozporządzenia ws. dokumentacji). Wiąże się to ze znacznymi kosztami, które wzrastają w momencie zaistnienia konieczności zniszczenia dokumentacji po okresie archiwizacji (art. 29 ust. 2 u.p.p.). Znaczne nieprawidłowości w prowadzeniu i przechowywaniu dokumentacji medycznej w formie tradycyjnej ujawnił raport Najwyższej Izby Kontroli ${ }^{34}$. Kontrola objęła 1730 indywidualnych dokumentacji medycznych prowadzonych przez łącznie 24 placówki zdrowotne na terenie siedmiu województw. Uchybienia w zakresie przechowywania dokumentacji medycznej odnotowano w aż 46\% przypadków, czego skrajnym przykładem było przechowywanie dokumentacji medycznej w drewnianych, niezamykanych szafach stojących na korytarzu, do których dostęp miały osoby trzecie (inni pacjenci, interesanci) ${ }^{35}$. Kontrolerzy NIK nie stwierdzili natomiast znaczących nieprawidłowości w prowadzeniu i przechowywaniu dokumentacji medycznej w postaci elektronicznej. Ze względu na właściwość dokumentu elektronicznego przechowywanie elektronicznej dokumentacji medycznej jest łatwiejsze. Zapoznanie się z jej treścią jest bowiem możliwe dzięki odczytywaniu zapisu cyfrowego na urządzeniu elektronicznym. Możliwe jest przy tym wdrożenie takich rozwiązań informatycznych, które pozwolą dokonać weryfikacji osób odczytujących te dane oraz zablokować dostęp podmiotom nieuprawnionym. Ponadto dokumentacja elektroniczna charakteryzuje się znaczną odpornością na

33 Na przykład przez okres 30 lat przechowywana jest dokumentacja medyczna pacjenta, który zmarł na skutek uszkodzenia ciała lub zatrucia. Termin ten liczony jest od końca roku kalendarzowego, w którym nastąpił zgon (art. 29 ust. 1 pkt 1 u.p.p.).

34 Informacja o wynikach kontroli Tworzenie $i$ udostęnianie dokumentacji medycznej, KZD.430.002.2015, nr ewid. 199/2015/P/15/061/KZD, s. 2-3.

35 Ibidem, s. 11. 
zniszczenie, utratę czy uszkodzenie ${ }^{36}$. W standardowych systemach komputerowych skorzystanie z komendy „usuń,, co do zasady, nie dezintegruje dokumentu elektronicznego, ale raczej ukrywa go w niewidocznej dla użytkownika przestrzeni, pozostając możliwym do przywrócenia ${ }^{37}$. Nie chroni to oczywiście przed intencyjnym usunięciem danych, ale raczej przed przypadkową ich utratą.

$\mathrm{Z}$ punktu widzenia lekarza prowadzenie dokumentacji medycznej w postaci elektronicznej jest wygodniejsze i praktyczniejsze, czyniąc proces diagnostyczno-terapeutyczny efektywniejszym oraz sprawniejszym. Bardzo często pacjent podejmuje decyzję o zmianie podmiotu leczniczego w trakcie trwania leczenia bądź wznawia je w innej placówce ochrony zdrowia. Prowadzenie elektronicznej dokumentacji medycznej umożliwia łatwe, bezpieczne, szybkie oraz tanie dostarczenie informacji medycznej do innego podmiotu udzielającego świadczeń opieki zdrowotnej, bez konieczności angażowania w ten proces pacjenta, szczególnie, gdy odbywa się w ramach jednego zintegrowanego systemu teleinformatycznego (jakim jest System Informacji Medycznej). Co niezwykle istotne tak przekazane dane medyczne będą pełne, a zatem aktualnie prowadzący leczenie lekarz ma kompletną historię choroby oraz stosowanej terapii, co nie tylko stanowi znaczną korzyść dla zdrowia pacjenta, ale gwarantuje jakiś stopień pewności i komfortu samemu medykowi, który nie ustala stanu zdrowia pacjenta wyłącznie na podstawie własnych badań i fragmentarycznej wiedzy o jego zdrowotnej przeszłości ${ }^{38}$. Cechą dokumentu elektronicznego umożliwiającą jego wielokrotne wygenerowanie oraz zapisywanie na różnych nośnikach informacji bez utraty integralności i autentyczności tego dokumentu jest multiplikowalność ${ }^{39}$.

Tworzenie dokumentacji medycznej w postaci elektronicznej ${ }^{40}$ odbywa się z wykorzystaniem oprogramowania na urządzeniach elektronicznych. Daje to możliwość opracowania odpowiednich do pracy lekarza edytorów tekstowych, kalkulacyjnych czy programów do odtwarzania plików. Może to znacznie usprawnić proces tworzenia dokumentacji medycznej, zapewnić jej kompletność (na przykład poprzez stosowanie formularza, którego poszczególne pola wymagałyby wypełnienia do utworzenia dokumentu), a także jej czytelność i klarowność.

W kontekście prawa pacjenta do informacji oraz dostępu do dokumentacji medycznej niebagatelne znaczenie mają korzyści związane ze sposobem udostępniania elektronicznej dokumentacji medycznej. Prowadzenie dokumentacji medycznej w postaci elektronicznej umożliwia bowiem przekazanie jej pacjentowi bez jego fizycznej obecności w placówce leczniczej, co stanowi niejednokrotnie

36 B. Freedman, Discovery of Electronic Records under Candian Law - A Practical Guide, „Intellectual Property Journal” 2004, nr 59, s. 1, WestLaw.

37 Ibidem.

38 A. Klich, K. Smyk, op. cit.

39 D. Szostek, Komentarz..., s. 77.

40 Chodzi oczywiście o dokumentację medyczną występującą w pierwotnej postaci jako dokumentacja elektroniczna, nie zaś dokumentację papierową, która została zdigitalizowana. 
barierę fiskalną (poniesienie kosztów dojazdu do danej jednostki) bądź faktyczną (stan zdrowia, niepełnosprawność). Dokumentacja medyczna może zostać przekazana pacjentowi za pomocą środków komunikacji elektronicznej (art. 27 pkt 4 u.p.p.), a zatem z zastosowaniem rozwiązań technicznych, w tym urządzeń teleinformatycznych i współpracujących z nimi narzędzi programowych, umożliwiających indywidualne porozumiewanie się na odległość przy wykorzystaniu transmisji danych między systemami teleinformatycznymi ${ }^{41}$. Podstawą przekazywania dokumentacji jest $\mathrm{w}$ tym wypadku elektroniczne przetwarzanie danych ${ }^{42}$, a zatem możliwe jest skorzystanie z poczty elektronicznej czy systemu teleinformatycznego ${ }^{43}$. Ten drugi sposób udostępniania elektronicznej dokumentacji medycznej będzie możliwy od dnia 1 stycznia 2021 roku dzięki obowiązkowemu wprowadzaniu dokumentacji medycznej prowadzonej w postaci elektronicznej do Systemu Informacji Medycznej (§ 11 rozporządzenia ws. dokumentacji). System ten opiera się na modelu chmury obliczeniowej ${ }^{44}$, a samo udostępnianie danych $\mathrm{w}$ jego ramach odbywa się $\mathrm{w}$ procesie przygotowywania i przesyłania odpowiednich komunikatów ${ }^{45}$.

Podstawowym problemem zauważanym z perspektywy pacjenta może być faktyczny, a dokładnie techniczny dostęp do dokumentacji medycznej przetwarzanej w systemie teleinformatycznym. Pomimo dynamicznie postępującej informatyzacji życia społecznego oraz gospodarki nadal w Polsce występuje zjawisko wykluczenia cyfrowego, obejmującego przede wszystkim osoby starsze, lecz także osoby, które ze względu na niekorzystną sytuację finansową nie posiadają komputera i nie mają dostępu do Internetu ${ }^{46}$. Takie osoby mogą nie tylko być pozbawione możliwości uzyskania dostępu do dokumentacji medycznej z własnego domu, lecz także mogą wymagać pomocy przy obsłudze urządzenia elektronicznego udostępnionego im w placówce leczniczej celem bezpośredniego wglądu do bazy danych. Ostatecznie najdogodniejszym rozwiązaniem będzie dla nich pozyskanie wydruku takiej dokumentacji, a zatem wygenerowanie dokumentu w tradycyjnej postaci.

41 Definicja według art. 2 pkt 5 ustawy z dnia 18 lipca 2002 roku o świadczeniu usług drogą elektroniczną (Dz.U. z 2016 r., poz. 1030, ze zm.).

42 D. Szostek, Czynność prawna a środki komunikacji elektronicznej, Kraków 2004, s. 35.

43 Nie jest natomiast możliwe udostępnienie dokumentacji medycznej za pomocą faksu (por. wyrok Naczelnego Sądu Administracyjnego z dnia 11 października 2016 roku, I OSK 966/15, Legalis) czy podczas rozmowy telefonicznej (por. wyrok Naczelnego Sądu Administracyjnego z dnia 26 lipca 2016 roku, II OSK 913/16, Legalis).

44 A. Romaszewski, W. Trąbka, Aspekty prawne przetwarzania danych medycznych w chmurach obliczeniowych, „Zeszyt Naukowy.pl” 2014, nr 33, s. 36.

45 Rozporządzenie Ministra Zdrowia z 28 marca 2013 roku w sprawie wymagań dla Systemu Informacji Medycznej (Dz.U. z 2013 r., poz. 463, ze zm.), § 5 i § 8, dalej „rozporządzenie ws. SIM”.

46 Wykluczenie cyfrowe. Opracowanie tematyczne OT-637, Warszawa 2015; Internauci 2015, Raport CBOS nr 90/2015, Warszawa 2015. 
Osobnym problemem może okazać się trudność w uwierzytelnieniu podmiotu występującego o dostęp do dokumentacji medycznej w systemie teleinformatycznym ( 5 pkt 3 rozporządzenia ws. SIM). Weryfikacja uprawnień zamawiającego odbywa się na zasadach określonych $\mathrm{w}$ odpowiednich przepisach u.i.d.p. ${ }^{47}$, a zatem z wykorzystaniem jednego z trzech sposobów uwierzytelniania: a) użycie notyfikowanego środka identyfikacji elektronicznej, adekwatnie do poziomu bezpieczeństwa; b) wykorzystanie profilu zaufanego ePUAP; c) wykorzystanie kwalifikowanego podpisu elektronicznego. Identyfikacja podmiotu w Systemie Informacji Medycznej odbywa się zatem z wykorzystaniem rozwiązań technicznych, które w praktyce są dla przeważającej części polskiego społeczeństwa obce. Zgodnie ze statystykami na dzień 31 grudnia 2014 roku profil zaufany ePUAP miało zaledwie 336896 użytkowników, z czego większą część stanowiły jednostki organizacyjne (w tym także podmioty publiczne) ${ }^{48}$. Tymczasem aktywnych certyfikatów kwalifikowanych podpisów elektronicznych na dzień 6 maja 2014 roku było jedynie $295158^{49}$, co wiąże się w głównej mierze z koniecznością ponoszenia znacznych opłat oraz stosowania sprzętu i infrastruktury informatycznej ${ }^{50}$. Oznacza to, że najprawdopodobniej przeciętny pacjent nie będzie miał możliwości uwierzytelnienia swoich danych w Systemie Informacji Medycznej, a co za tym idzie - dostępu do dokumentacji medycznej przesłanej w formie stosownego komunikatu.

Podstawowym wyzwaniem związanym z prowadzeniem dokumentacji medycznej w postaci elektronicznej jest zapewnienie odpowiedniego poziomu zabezpieczenia danych osobowych. Dane medyczne należą do kategorii danych wrażliwych, o których mowa w art. 27 u.o.d.o. ${ }^{51}$, jako że są ściśle związane z prywatnością człowieka, a przez to ich przetwarzanie powoduje większe poczucie niebezpieczeństwa ${ }^{52}$. Stąd też ich wykorzystywanie do celów związanych z ochroną zdrowia jest wyjątkiem i powinno odbywać się w sposób ściśle zabezpieczający przez dostępem osób nieuprawnionych, rozpowszechnieniem, ingerencją oraz utratą. Jest to o tyle istotne, że dane medyczne stanowią niezwykle cenne informacje pozwalające na określenie zbiorczych oraz indywidualnych cech odbiorców

47 Ustawa z dnia 17 lutego 2005 roku o informatyzacji działalności podmiotów realizujących zadania publiczne (Dz.U. z 2014 r., poz. 1114, ze zm.), dalej „u.i.d.p.”.

48 „Gazeta Prawna.pl”, http://prawo.gazetaprawna.pl/artykuly/844832,ponad-1-5-mln-dokumentow-wyslanych-za-pomoca-epuap-w-2014-roku.html (dostęp: 10.02.2017).

49 Ministerstwo Gospodarki, http://www.mg.gov.pl/Wspieranie+przedsiebiorczosci/Dzialalnosc+gospodarcza+i+e-przedsiebiorczosc/Podpis+elektroniczny (dostęp: 10.02.2017).

50 W. Nowakowski, Analiza stanu zastosowań podpisu elektronicznego w Polsce, ,Elektronika" 2011, nr 11, s. 102.

51 Ustawa z dnia 29 sierpnia 1997 roku o ochronie danych osobowych (Dz.U. z 2016 r. poz. 922), dalej „u.o.d.o.”.

52 P. Barta, Komentarz do art. 27, [w:] Ustawa o ochronie danych osobowych. Komentarz, P. Barta, P. Litwiński, Legalis. 
pewnych usług medycznych czy leków ${ }^{53}$. Ochrona danych osobowych jest obecnie jednym z najważniejszych obszarów działań prawodawcy europejskiego, który podjął działania mające na celu zapewnienie jednolitego standardu tej ochrony w państwach członkowskich (tak zwane RODO ${ }^{54}$ ) odnoszące się w znacznej części do zagadnienia danych dotyczących zdrowia. Rozporządzenie to weszło w życie 25 maja 2018 roku, wobec czego polski ustawodawca stoi obecnie przed zadaniem zrewidowania dotychczasowego systemu ochrony danych osobowych i konieczności zapewnienia mechanizmów odpowiadających standardom unijnym. Nie ulega wątpliwości, że wprowadzenie kompleksowej i pełnej regulacji ochrony danych medycznych jest $\mathrm{w}$ dobie postępującej informatyzacji procesu udzielania świadczeń zdrowotnych i przetwarzania dokumentacji medycznej w systemach teleinformatycznych osią działań w zakresie organizacji ochrony zdrowia.

\section{Wnioski}

Prawo pacjenta do dokumentacji medycznej jest szczególnym rodzajem szerszego uprawnienia informacyjnego, pełniąc zarówno funkcje gwarancyjne, jak i stanowiąc warunek legalizacji udzielania świadczeń zdrowotnych. Rozwój medycyny umożliwił pacjentom korzystanie z nowoczesnych form terapii, przyczyniając się do powstania zjawiska turystyki medycznej. Współczesny pacjent rzadko korzysta ze świadczeń jednej placówki leczniczej przez całe swoje życie. Z uwagi na rozproszenie lokalizacyjne placówek leczniczych, z których świadczeń korzysta pacjent, a także znaczne odstępy czasowe w podejmowanym leczeniu, kluczowe znaczenie ma zapewnienie pacjentowi łatwego, bezpiecznego, taniego i szybkiego dostępu do pełnej dokumentacji medycznej.

Jest to możliwe dzięki wykorzystaniu nowoczesnych rozwiązań technologicznych w ochronie zdrowia poprzez wdrożenie zintegrowanego systemu teleinformatycznego, w którym przetwarzane są dane medyczne wprowadzone przez każdy podmiot świadczący opiekę zdrowotną w publicznym sektorze. Uruchomienie udostępniania elektronicznej dokumentacji medycznej w Systemie Informacji Medycznej stanowi dla państwa znaczące wyzwanie organizacyjne, techniczne i finansowe. Samą ideę leżącą u podstaw zastosowania takiego rozwiązania w ochronie zdrowia należy ocenić pozytywnie. Zarówno prowadzenie dokumentacji medycznej w postaci elektronicznej, jak i jej przetwarzanie i przekazywa-

53 Nie jest to problem dostrzeżony wyłącznie w krajach europejskich, por. D. Chunyan, Patient Privacy Protection in China in the Age of Electronic Health Records, „Hong Kong Law Journal” 2013, nr 245, WestLaw; A. Thorogood et. al., Protecting the Privacy of Canadians' Health Information in the Cloud, „Candian Journal of Law and Technology” 2016, nr 173, WestLaw.

54 Rozporządzenie Parlamentu Europejskiego i Rady (UE) 2016/679 z dnia 27 kwietnia 2016 roku w sprawie ochrony osób fizycznych w związku z przetwarzaniem danych osobowych i w sprawie swobodnego przepływu takich danych oraz uchylenia dyrektywy 95/46/WE (ogólne rozporządzenie o ochronie danych) (Dz.Urz. UE L 119/1), dalej „RODO”. 
nie jest racjonalniejsze $\mathrm{z}$ punktu widzenia ekonomii. W praktyce skorzystanie z art. 11 u.o.s.i.z., w którym pacjenci upatrują z nadzieją szansy na ułatwienie procesu pozyskiwania dokumentacji medycznej, może okazać się dla nich niemożliwe. Barierą będzie przede wszystkim konieczność uwierzytelnienia podmiotu występującego o dostęp do dokumentacji za pomocą narzędzi, które nie są wykorzystywane w codziennym życiu przez znaczną część społeczeństwa. Pacjentom pozostaną do dyspozycji inne sposoby uzyskania dostępu do dokumentacji, jak wgląd do bazy danych, pozyskanie wydruków z systemu czy też zapisanie danych na informatycznym nośniku danych, wiążące się z koniecznością fizycznego odwiedzenia placówki leczniczej przechowującej dokumentację.

Sztandarowe hasło planowanej nowelizacji, głoszące prosty i komfortowy dostęp do dokumentacji medycznej pacjentów w ich własnych domach, może okazać się fikcją zbudowaną na społecznych oczekiwaniach. Niemniej sam obowiązek prowadzenia dokumentacji medycznej wyłącznie w postaci elektronicznej ma szansę zrewolucjonizować funkcjonowanie opieki zdrowotnej i zdecydowanie podnieść jakość udzielanych świadczeń. Jakkolwiek pacjent będzie miał problem z weryfikacją uprawnień w Systemie Informacji Medycznej, dany podmiot świadczący opiekę zdrowotną w ramach powszechnego systemu bez problemu zostanie zidentyfikowany jako autoryzowany do uzyskania dostępu, gdyż co do zasady takie jednostki mają profil zaufany ePUAP bądź korzystają z innego sposobu uwierzytelnienia w rejestrach medycznych.

Rozwój nowych technologii i jej zastosowanie w medycynie jest nieuniknione. Wobec dynamicznych przemian społecznych oraz zwiększającej się świadomości pacjentów w zakresie przysługujących im praw oraz sposobów ich egzekwowania planowane przez ustawodawcę zmiany są niezbędne. Praktyka jednak zweryfikuje, w jakim stopniu proponowane rozwiązania są skuteczne i w jakim zakresie faktycznie odmieniły życie pacjentów.

\section{Bibliografia}

Barta P., Komentarz do art. 27, [w:] Ustawa o ochronie danych osobowych. Komentarz, P. Barta, P. Litwiński, Legalis.

Bączyk-Rozwadowska K., Prawo pacjenta do informacji według przepisów polskiego prawa medycznego, „Studia Iuridica Toruniensia” 9, 2011, nr 2.

Bernatek-Zaguła I., Prawo pacjenta do informacji zawartej $w$ dokumentacji medycznej, „Przegląd Prawa i Administracji” 69, 2005.

Chunyan D., Patient Privacy Protection in China in the Age of Electronic Health Records, „Hong Kong Law Journal” 2013, nr 245.

Dokumentacja medyczna, red. U. Drozdowska, Warszawa 2012.

Drozdowska U., Wojtal W., Zgoda i informowanie pacjenta, Warszawa 2010.

Dukiet-Nagórska T., Świadoma zgoda pacjenta w ustawodawstwie polskim, „Prawo i Medycyna" 2000, nr 6-7.

Fraser H., Biondich P., Moodley D., Choi S., Mamlin B., Szolovits P., Implementing electronic medical record systems in developing countries, ,Informatics in Primary Care” 2005, nr 13. 
Frąckowiak H., Postępowanie przed wojewódzka komisją do spraw orzekania o zdarzeniach medycznych, Warszawa 2016.

Freedman B., Discovery of Elecrtonic Records under Candian Law - A Practical Guide, „Intellectual Property Journal" 2004, nr 59.

Janiszewska B., Zgoda na udzielenie świadczenia zdrowotnego. Ujęcie wewnątrzsystemowe, Warszawa 2013.

Jankowski J., Elektroniczny obrót prawny, Warszawa 2008.

Katikireddi S.V., HINARI: Bridging the global information divide, „British Medical Journal” 2004, nr 328.

Klich A., Smyk K., Udostępnianie elektronicznej dokumentacji medycznej - zagadnienia praktyczne, [w:] E-państwo. E-obywatel. E-ustugi, red. K. Flaga-Gieruszyńska, J. Gołaczyński, D. Szostek, Warszawa 2017.

Kubiak R., Prawo medyczne, Warszawa 2010.

Kubiak R., Tajemnica medyczna, Warszawa 2015.

Leksykon prawa medycznego, red. A. Górski, Warszawa 2012.

Michałkowska K., Informowanie pacjenta w polskim prawie medycznym, „Prawo i Medycyna” 2003, nr 13.

Nowakowski W., Analiza stanu zastosowań podpisu elektronicznego w Polsce, „Elektronika” 2011, nr 11.

Pynt G., Australia: medical records - access by patient, „International Insurance Law Review” 1995, nr 3.

Radzicki J., Ryzyko zabiegów leczniczych w prawie karnym, Warszawa 1967.

Romaszewski A., Trąbka W., Aspekty prawne przetwarzania danych medycznych w chmurach obliczeniowych, „Zeszyt Naukowy.pl” 2014, nr 33.

Sośniak M., Obowiązek powiadomienia o skutkach zabiegu lekarskiego, „Państwo i Prawo” 1958, nr 7.

Szostek D., Czynność prawna a środki komunikacji elektronicznej, Kraków 2004.

Szostek D., Komentarz do art. $77^{3}$ Kodeksu cywilnego, [w:] Informatyzacja postępowania cywilnego. Komentarz, red. J. Gołaczyński, D. Szostek, Warszawa 2016.

Świtała K., Nowy system informacji ochrony zdrowia w kontekście Europejskiej Agendy Cyfrowej, „Czas Informacji” 2011, nr 4.

Thorogood A. et. al., Protecting the Privacy of Canadians' Health Information in the Cloud, „Candian Journal of Law and Technology" 2016, nr 173.

Wojsyk K., Informatyka w administracji publicznej nie przynosi oczekiwanych efektów ekonomicznych - i co ma do tego prawo?, [w:] Prawne problemy wykorzystania nowych technologii, red. K. Grajewski, J. Warylewski, Gdańsk 2008.

\section{The patient's right to access to electronic medical records}

\section{Summary}

Patient's right to medical records is a particular type of broader right to information, simultaneously serving guarantee function and conditioning of the legalization of granting health services. The development of medicine has enabled patients to seek for modern forms of therapy, contributing creation of the medical tourism. Rarely, patients benefit from health care served by one institution through their whole lives. Due to the dispersion of localization treatment facilities, from which patient gets healthcare, as well as significant intervals in the treatment, it is crucial to ensure that the patient has easy, safe, cheap and fast access to the full medical records. 
This is possible through the use of modern technology in health care by the implementation of integrated information and communication system, in which medical data introduced by any public healthcare provider are processed. Sharing of electronic medical records in the Medical Information System represents a significant challenge to the organizational, technical and financial resources for the state. The very idea underlying application of such solutions in health care should be assessed positively. Both keeping medical records in electronic form, as well as its processing and transmission is more rational from the economic point of view. However, in practice, using this technique, in which patients expects chance for facilitation accessing to medical records, may not be able. Main obstacle may be necessity of ordering entity authentication performer with tools that are not used in everyday life by significant part of society.

Regardless of the above, obligation of conducting medical records in electronic form is going to transform organization of health care and raise the quality of medical service. Commonly medical institution, which provides health care in frames of public system, has the trusted profile ePUAP or use other method of identification.

Towards dynamic social changes and increasing patients awareness of their rights, revisions planned by the legislative are necessary. Nevertheless, practice will review efficiency of those solutions and their influence on patients' lives. 